\title{
TERRAIN DRAINAGE IN THE LANDSLIDE AREA ON THE DANUBE SLOPE IN NOVI SAD
}

\author{
Milinko Vasić, Mitar Djogo, Branko Jelisavac
}

Professional paper

The landslide in the zone of the Sloboda Bridge in Novi Sad is one of the most extensively researched landslides in Serbia because it is large and it poses a threat to the stability of the aforementioned bridge over the Danube. At the time of its completion in 1981, this cantilever-spar cable-stayed bridge was the largest in the world, with a central span of $351 \mathrm{~m}$. In the body of the landslide, the bridge is founded on reinforced concrete piles $27 \mathrm{~m}$ in length. The measured depth of movement for the first part of the sliding mass is $26 \mathrm{~m}$, while that of the second one is $35 \mathrm{~m}$. The designed drainage structures consist of the following: two wells with diameters of $6,5 \mathrm{~m}$ and depths of $22 \mathrm{~m}$, eight drains with lengths of $45 \mathrm{~m}$ and a drainage tunnel linking the pressure chamber and the wells.

Keywords: drainage structures; landslide; monitoring

\section{Dreniranje terena u zoni klizišta na Dunavskoj padini u Novom Sadu}

Stručni članak

Klizište u zoni mosta Slobode u Novom Sadu je jedno od najviše istraživanih klizišta u Srbiji iz razloga što predstavlja ozbiljnu prijetnju po stabilnost pomenutog mosta preko Dunava. U vrijeme završetka izgradnje 1981. godine, ovaj most s kosim kablovima, bio je na svijetu s najvećim središnjim rasponom od $351 \mathrm{~m}$. U tijelu klizišta, most je temeljen na armiranobetonskim pilotima duljine $27 \mathrm{~m}$. Utvrđena dubina pomicanja za prvi klizni blok iznosi $26 \mathrm{~m}$, a za drugi $35 \mathrm{~m}$. Projektirani drenažni sustav se sastoji od slijedećeg: dva bunara s promjerom od 6,5 m i dubine $22 \mathrm{~m}$, osam drenova duljine do $45 \mathrm{~m}$ i drenažnog tunela koji spaja potisnu komoru i bunare.

Ključne riječi: drenaže; klizište; nadzor

\section{Introduction}

Landslides on the right bank of the Danube in Serbia are large and deep and have very specific features. Their specific nature is such that the sliding along deep sliding planes occurs very slowly, namely, at approximately $1 \mathrm{~cm}$ per year. In Serbia, landslides of this sort prevail in an area of approximately $100 \mathrm{~km}$ along the right bank of the Danube. In this study, landslides near the Danube are analysed in a manner similar to the studies performed in the literature $[1,2,3]$. Along this stretch of land, there are only small areas that do not have landslides [4]. Unfortunately, landslide-prone areas were impossible to avoid, especially during the construction of the BelgradeBudapest motorway and railroad. Many researchers have studied this type of landslide in the past [5]; some researchers suggested hypotheses to explain the causes of landslides along the Danube. Among the first such papers was that of Luković [6]. Perić's [7] hypothesis was based on the premise that artesian water in the aquiferous sand below the Danube river bed causes soil breakage in the area surrounding the Danube. A more recent hypothesis was based on the premise that tectonic movement causes the landslide areas to rise and that the sliding is caused by faults in the terrain and tectonic events [8].

This paper demonstrates that the main causes behind the creation of landslides are the following: sediments that are mildly tilted towards the Danube; the frequency of low-resistance sediments along which the sliding takes place; the influence of groundwater flowing from the slope part of the terrain into the landslide; and the Danube itself, due to its deep river bed that erodes the right river bank. Investigations have determined the size of the landslide and its factors and causes, and countermeasures have been proposed to stabilise the landslide. The slow movement of this landslide allows the process to be monitored and measurements to be taken over a long period of time [9]. Detailed investigations and reliable data on the landslide allow the partial implementation of countermeasures and the monitoring of their effect on landslide stabilisation. Landslides in the area surrounding the Sloboda Bridge are shown in Fig. 1.

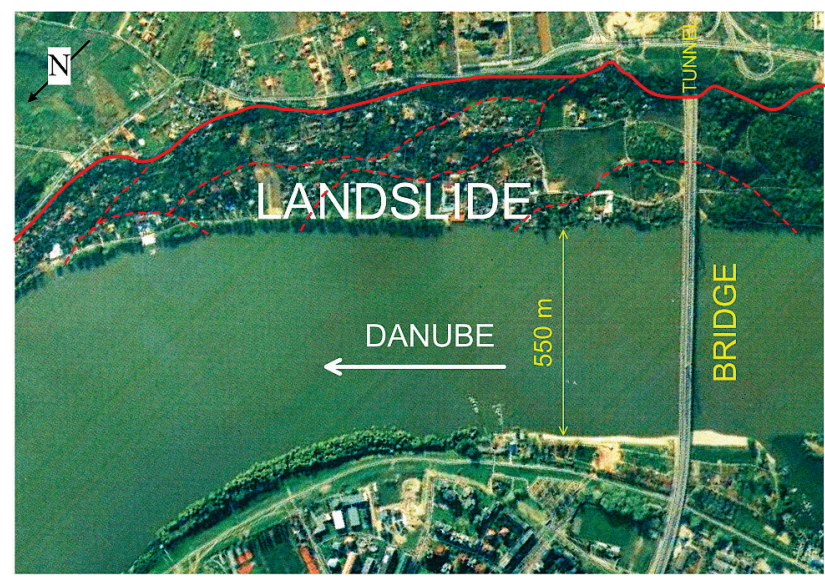

Figure 1 Location map of the study area

On the right bank of the Danube, the pillars of the bridge were founded on relatively deep piles (Fig. 2) except for the final pillar, number 22, which was founded on a raft without piles. As an example, pylon pillar number 17 has a total of six groups of four (i.e., 24) piles with diameter $150 \mathrm{~cm}$ located $27 \mathrm{~m}$ deep below the pile cap. Pillar numbers 18, 19, 20 and 21 were also founded on piles. The bases of the piles below pylon pillar 17 reach down to the deepest sliding planes; the other pillars were founded on shallow piles that are situated in the body of the landslide. It is absolutely certain that they did not penetrate the stable base of the landslide (Fig. 3).

As the landslide moves, the pillars of the bridge move along with it. The movements of the pillars are being geodetically measured. Based on these measurements, it 
is possible to analyse the dynamics by which the landslide and the bridge are moving. Generally speaking, pillars $17-$ 21 have moved an average of $6 \mathrm{~mm} /$ year over the past 28 years [9]. The movements of the bridge pillars and those of the inclinometers have been identical. The results of years of measurement were crucial for forming the decision that the unstable slope in the area around the bridge must be stabilised.

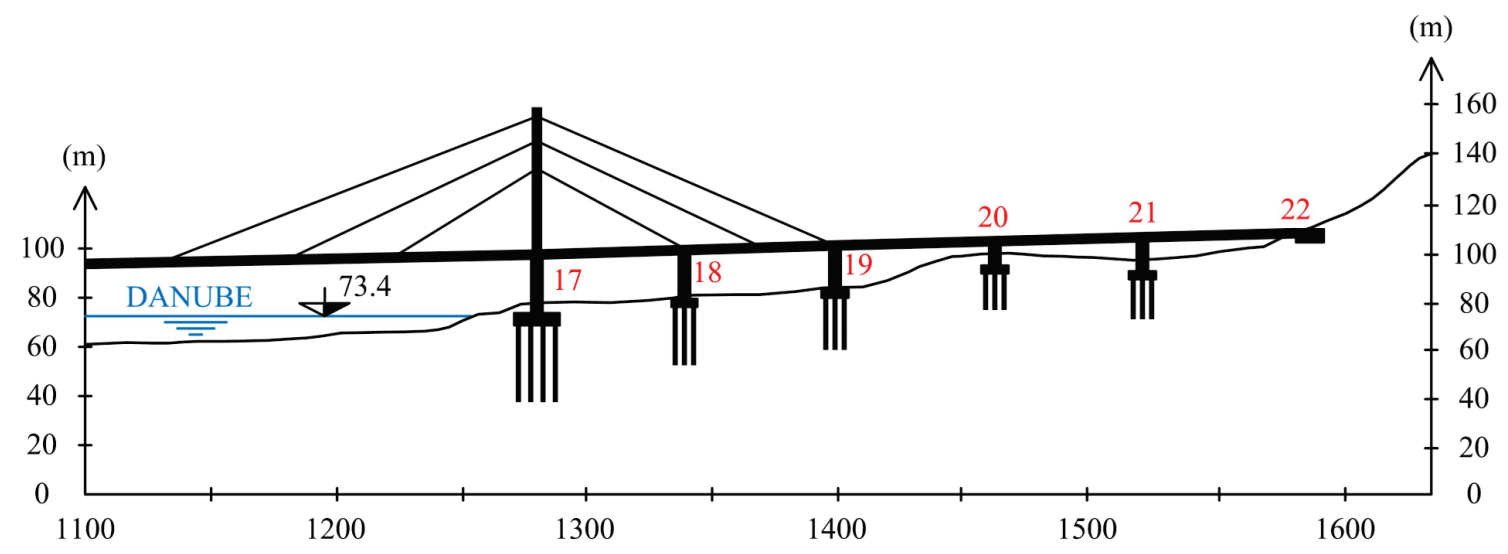

(m)

Figure 2 The bridge and piles on the right bank of the Danube

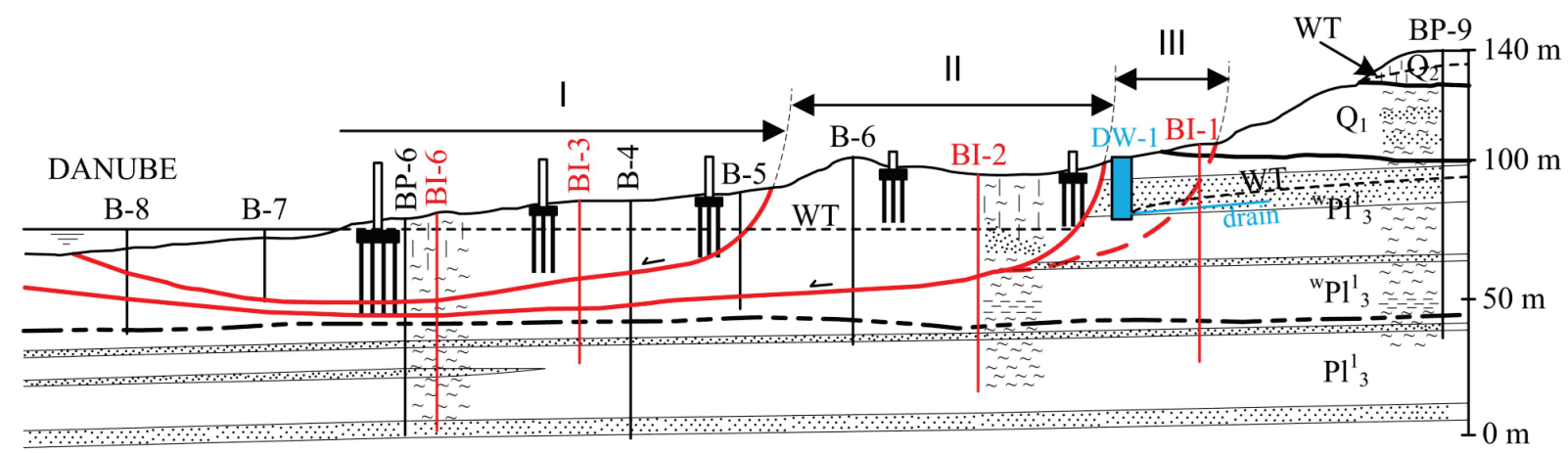

LEGEND:

marl

$\mathrm{Q}_{2}$ - Loess

$\mathrm{BP}$ - Borehole with piezometer

$\mathrm{Q}_{1}$ - Srem series - clay, gravel, sand

B - Research borehole

${ }^{\mathrm{W}} \mathrm{Pl}_{3}{ }_{3}$ - Altered marls and clays with sand layers

DW-1 - Drainage well 1

$\mathrm{Pl}^{1}{ }_{3}$ - Unaltered marls and clays with sand layers

I - First part of sliding mass

Vliding plane

II - Second part of sliding mass

BI - Borehole with inclinometer

III - Third part of potentially sliding mass

Boundary beetwen altered and unaltered sediments

WT - water table

Figure 3 Geological and Geotechnical Cross-section of the study area

\section{Geological setting}

Investigatory boreholes ascertained that the stationary-stable part of the terrain, in its deepest part, is made up of shallow-water Pliocene sediments or so-called paludin layers. This was confirmed by the discovery and identification of certain representative fossil remains. From a lithological viewpoint, the sediments are present mainly in grey marl clay and in aleurites, which are also grey in colour. Sands are substantially less present. In addition to the listed sediments, coal clay, red marl and lignite layers are also present. All of the listed sediments are clearly layered and are inclined towards the Danube at an angle of $2^{\circ} \div 5^{\circ}$ (Fig. 3)

The younger part of the Pliocene sediments is without fossil remains, and it is likely that it belongs to younger levels of medium paludin layers. In a lithological sense, grey and grey-brown clay prevails alongside sandy clay and individual layers of sand and sandy aleurites. To a slightly lesser extent, these sediments contain layers of sandy gravel and individual layers of sandstone. The sand horizon in the youngest part of the Pliocene is of particular importance from the point-of-view of this research. It is through these laterally continuous sand layers that the largest amount of groundwater flows into 
the landslide surface and the body of the landslide. Based on data from drainage well DW-1 (Fig. 3), the horizon of the Pliocene sand was found at a depth of 7,50 $\div 19,40 \mathrm{~m}$. The horizon consisted of several layers of sandstone partially bound by $\mathrm{CaCO}_{3}$ components and thin inner layers of clay. However, those clay layers do not represent absolute barriers to the movement of groundwater.

At their shallowest parts or in zones immediately below Quaternary sediments, the Pliocene sediments are altered and enriched with $\mathrm{CaCO}_{3}$ [10]. This area is interesting from the aspect of studies of the process of surface decomposition of marl sediments in the distant past and marking of the sliding process compared to age. Likewise, characteristic geological markers may be found in the immediate under-layer of the slide such as coal clay and red-stripe marl. These have been discovered in all of the borehole cores.

Coal clays are a very small percentage of the makeup of Pliocene marl-clay sediments. They can usually be found in the form of layers or sometimes as thin lenses only a few centimetres up to a few decimetres thick. They can be found in somewhat larger amounts only in the contact zone between the altered and unaltered Pliocene sediments at an approximate elevation of $44 \div 46 \mathrm{~m}$. Despite their minute presence, their significance and influence on the sliding activities of the terrain are extremely large. As a rule, shearing resistance parameters in such an environment have very small value, and these plans are most prone to sliding.

Loess represents the youngest sediment in the stable part of the terrain $[11,12]$. In borehole BP-9, which was drilled on the loess plane, two horizons of soil loess were recorded with another layer of fossil soil in between. The thickness of the loess deposits together with the fossil soil is $13,2 \mathrm{~m}$. Loess acted as a stabilising factor in previous landslides that formed on the slope before it had accumulated.

The contact zone between the stable under-layer and the body of the landslide is the sliding zone in which occasional shearing and sliding of the sliding body occurs. The existence of a sliding zone has been confirmed in all of the boreholes. The zone is formed mostly from coal clay and less so from marl and marl clay. The thickness of the zone is several metres, it is intensively fragmented and all of the moving surfaces are extremely smooth. Numerous shallower sliding zones were confirmed in all the boreholes in addition to the deepest sliding zones.

In the wider area of the bridge, detailed geomorphological analyses have registered no neotectonic active faults; therefore, their influence on the process of sliding is non-existent.

\section{Hydro-geological properties of the terrain}

Information about the hydro-geological properties of the terrain was gathered through the analysis of measurements from classic and electric piezometers and permeability experiments both in the laboratory and under field conditions. It was determined that an aquifer exists in the body of the landslide with variable levels of underground water depending upon precipitation, water inflow from the sand horizons and the background of the landslide and the activity of the constructed drainage system. From the stable part of the terrain, that is, from the background of the landslide, the landslide receives a significant supply of water from the sand of the Srem series and especially from Pliocene sand horizons that have been found in borehole BP-9 at a depth of 41,30 $54,10 \mathrm{~m}$ (Fig. 3). This horizon of Pliocene sand has been interrupted by the landslide head scar, and the position it has taken up within the body of the landslide is dictated by the sliding process. The presence of three significant layers of sand was confirmed in the deeper parts of the stable terrain, i.e., at borehole BP-6 within the Pliocene. These layers were found at the following depths: $45,80 \div$ $47,00 \mathrm{~m} ; 57,20 \div 59,20 \mathrm{~m}$; and from 75,90 to approximately $85,00 \mathrm{~m}$. Within all three layers of sand, electric piezometers have confirmed the presence of groundwater with sub-artesian pressure, and only in BP-6 has groundwater at artesian pressure been discovered within the deepest horizon of sand. Thick and practically watertight layers of marl and marl clay can be found between the aforementioned layers of sand. Investigation has shown that the groundwater from the sand layers (Fig. 3), which lie below the deepest sliding planes, has no influence on the sliding process.

Each electric piezometer installation contains three measuring cells produced by Soil Instruments Ltd; they were installed at three different depths each in a different layer of sand. Most of the measuring cells were installed within different layers of sand, but several cells were installed in the sliding zone. Each measuring cell is in the middle of a 3-m-long section of the borehole that was filled with sand to provide a high permeability between the cell and the ground; the rest of the borehole was filled using a mixture of cement and clay to provide a water seal between the cells.

\section{The characteristics of the landslide and its movements}

The lithogenic composition of the terrain was determined up to a depth of $104 \mathrm{~m}$ by the exploratory work that was carried out. Examinations of the cores of the exploratory boreholes along with measurements from the installed inclinometers determined the boundary between stable and unstable terrain [13]. It has been ascertained that the old-fossil landslide used to reach the limit of the unaltered Pliocene sediments (Fig. 3). Loess acted as a stabilising factor for the old landslides that formed on the slope before the loess accumulated.

Immediately after the installation of each of the inclinometers, measurements of movement began. Measurements were taken four times a year on average from 1992 to 2010.

Each of the inclinometers is operated by lowering the measuring probe to the bottom of the installed inclinometer structures. During the process of installing the inclinometer tubes, great care was taken to orient them in such a way that one set measured movements perpendicular to the flow of the Danube (A-B) while the other measurement plane was actually parallel to its flow (C-D).

This paper shows only the representative diagram of the movement (Fig. 4) relative to inclinometer BI-3. 


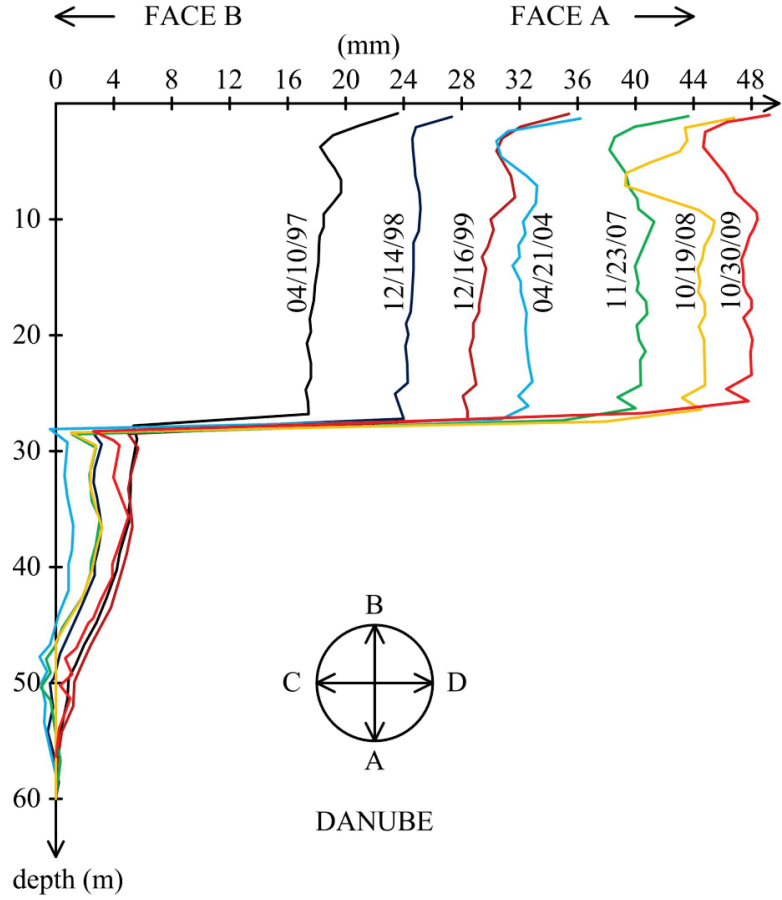

Figure 4 The results of movement measurements from inclinometer BI-3

The measurements taken by the inclinometers served the following purposes:

- determination of the full extent of the movements;

- analysis of the extent of depth-wise movement;

- analysis and comparison of movements along various sliding planes measured within the investigatory boreholes and during core inspection;

- comparison of movement across all inclinometers, that is, of certain blocks of the sliding body;

- prediction of the time periods in which the movements occurred;

- analysis of movements in the four measured directions (A, B, C and D);

- comparison of the results to geodetic observations of the movements from surface reference points; and

- comparison of measurement results to the level of groundwater and oscillations in the level of the Danube.

We understand with great certainty that movements registered by the inclinometers occur at several different depths. The extents of the movements are different at different depths but are based on cumulative movements; certain major areas and discontinuities can be distinguished where these movements are the greatest. At inclinometer BI-3, the most intensive sliding occurs at depths of approximately $28 \mathrm{~m}$ (elevation 57,7 m). As seen from the A-B measurement plane, the direction of the most extensive sliding is towards the Danube along the sliding planes that are slightly sloped towards the river.

The sliding zones were precisely determined by examining the borehole cores. These zones are characterised by a highly damaged borehole core with walls that were crushed together and a large number of shearing cracks. We concluded that the maximum movements registered on the inclinometers were at the same depth as the sliding zones registered in the borehole cores. The greatest movements occurred down the slope perpendicular to the flow of the Danube while smaller movements occurred in the upstream or downstream directions relative to the flow of the Danube.

Analyses of the movements of all seven inclinometers led to the conclusion that shallower landslides move across sliding planes at a depth of approximately $26 \mathrm{~m}$ (BI-6, BI-4, BI-5 and BI-3). Inclinometers BI-2 and BI-7 show relatively intense movements across the sliding plane at a depth of approximately $35 \mathrm{~m}$ [9]. Interestingly, inclinometer BI-1 registered highly intense movements only at a depth of approximately $10 \mathrm{~m}$. We interpret this result to mean that a deep landslide in the area of this inclinometer has still not been activated.

\section{Stability of landslide}

At the time when the bridge was designed and constructed (from 1976 to 1981), it was a known fact that there were active landslides on the right bank of the Danube. As a result, the bridge was founded on piles, and countermeasures were implemented to stabilise the unstable slope. The following work was carried out at the time: evening-out was performed on the surface terrain; surface channels were created to carry away precipitation and spring water; and a brief drainage was performed. Over the course of the bridge's lifespan, these measures proved to have been insufficient to stop the sliding process.

In 1995, work on landslide stabilisation resumed according to a new project design. The design's fundamental assumptions were based on the results of more recent and detailed geotechnical research and testing that allowed for a very high degree of landslide investigation and is presented in this paper. The order in which the countermeasures were to be implemented was adapted to meet the following demands:

- every countermeasure that is to be implemented should be monitored and controlled through the installed inclinometers;

- the implementation of one countermeasure does not hinder the possibility of observing the effects of subsequent measures; and

- the countermeasures must be implemented in stages because the dynamics of the sliding process allows it.

Mitigating the sliding does not require a simultaneous implementation of all of the countermeasures including their immediate and cooperative effects. Such an approach required that the bank revetment not be constructed first because it would be impossible to separate the effects of the bank revetment from that of other countermeasures. Additionally, it would not be possible to implement the alleviation of the slope during the first stage because that could change the pressure status in the terrain and cause the inclinometers to function under somewhat altered conditions. It was quite logical to first perform drainage of the groundwater from the background and partially from the body of the landslide. Such an operation changes practically nothing in the morphology of the adjacent terrain, and its effects are definitely positive for the following reasons: 
- it stops the inflow of groundwater into the sliding plane and the landslide;

- it removes the negative effects associated with hydrostatic and hydrodynamic pressures; and

- it causes an increase in the shearing parameters of the soil in certain areas of the landslide.

The repair measures (Fig. 5) consist of three stages:

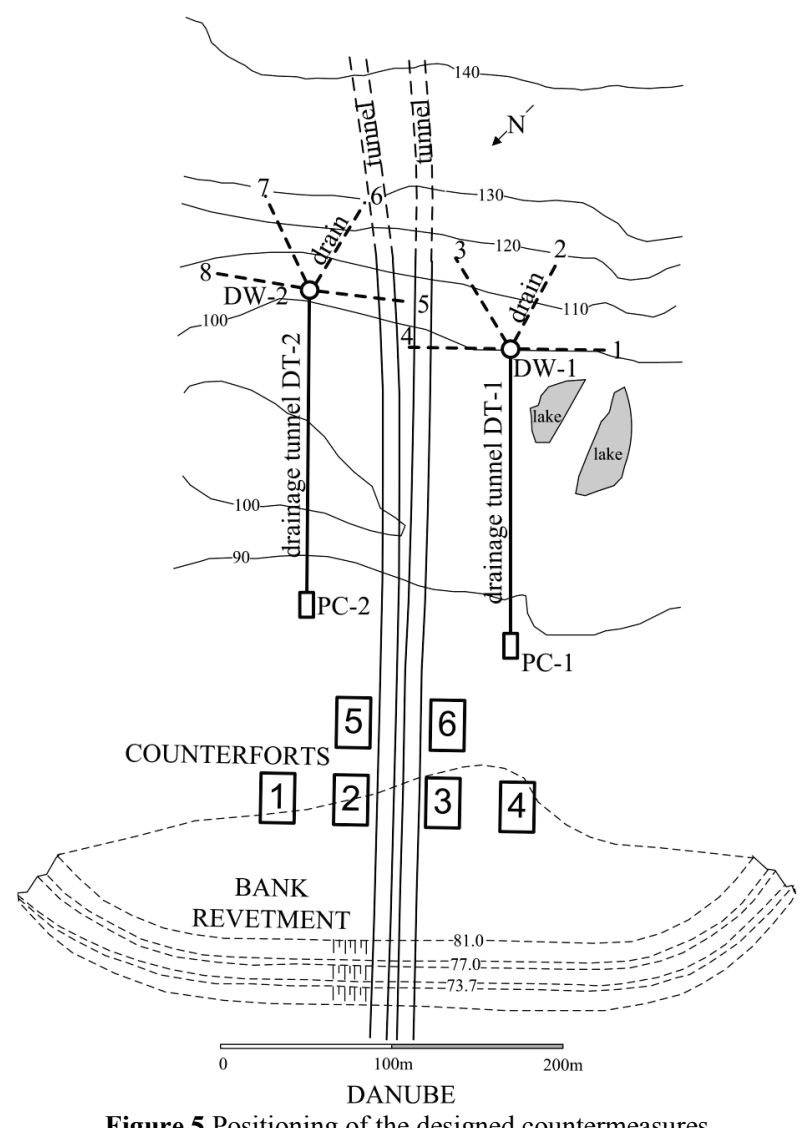

Figure 5 Positioning of the designed countermeasures

Stage I-a: the construction of drainage wells DW-1 and DW-2 consisting of four drains that lead from both wells. The drains are located in the Pliocene sand. The pressure chambers (PC) and the wells are connected by the drainage tunnels (DT).

Stage I-b: the insertion of drains from the surface terrain into the sandy-gravel sediments (the so-called Srem series), which are below the loess horizons.

Stage II: the construction of the bank revetment and alleviation and evening-out of the slope.

Stage III: the construction of six supporting structures consisting of counterforts on the lower level of the slope.

Since the solution was conceived and the implementation sequence of the countermeasures was established, almost all of the countermeasures listed in Stage I-a have been completed. Only the pressure chamber PC-2 and the drainage tunnel DT-2 leading to the well DW-2 (Fig. 5) were not constructed. The groundwater flows into both of the wells through the drainage channels, and it is then channelled from DW-1 through drainage tunnel DT-1 into the Danube in a controlled fashion. Bearing in mind that the drainage system leading from DW-2 was not realised, this well has not been performing its function of draining water from the background. Draining the terrain using the entire system in Stage I-a was supposed to have completely eliminated the negative effects of the groundwater. Thus, the drainage system described in Stage I-a needs to be completed as soon as possible.

The completed drainage wells DW-1 and DW-2 are $22 \mathrm{~m}$ deep and have internal diameters of $6,50 \mathrm{~m}$ and concrete walls $0,45 \mathrm{~m}$ thick. Four drains with lengths of $45 \mathrm{~m}$ lead from each of the wells. The drainage of water from these drainage wells was originally planned to be achieved using deep drainage protected by steel (Larsen) sheet pile sections. A drainage channel $2,7 \mathrm{~m}$ wide was to be fitted with a drainage pipe $1400 \mathrm{~mm}$ in diameter, and the excavation shaft from that pipe to the surface was to be filled in by drainage material made from crushed stone and gravel. Instead of this expensive drainage design, however, a new solution was accepted and implemented. From the pressure chamber to drainage well DW-1, laserguided reinforced concrete pipes were installed. The pipes were $1500 / 1840 \mathrm{~mm}$ in diameter and were installed at a length of $139 \mathrm{~m}$.

Stage II of the slope stabilisation had a design that incorporated a bank revetment whose far end would lie in the Danube river bed at a distance of approximately $75 \mathrm{~m}$ from pillar number 17.

Stage III involves six concrete box diaphragms (counterforts) made of reinforced concrete with rectangular bases of dimension $20 \mathrm{~m}$ by $30 \mathrm{~m}$ (Fig. 5). The thickness of their walls is approximately $0,50 \mathrm{~m}$. They span the entire length of the landslide and end in stable terrain. The basic function of concrete box diaphragms is to increase resistance parameters to the shearing of the soil in the sliding area within their area of effect. In addition, the unfavourable influences of the groundwater will be eliminated.

\section{Terrain drainage}

Comprehensive investigations have determined that significant quantities of groundwater are flowing into the landslide. Groundwater has a significant effect on the sliding process. To eliminate the effects of groundwater on the landslide, the terrain was drained. According to the geotechnical cross-section (Fig. 3), the largest amounts of groundwater flow in from pockets of Pliocene sands whose thickness is approximately $12 \mathrm{~m}$. The sands are interrupted by the landslide, but they are continual in the slope. The purpose of draining the terrain is to channel the groundwater from the sands into the drainage facilities in a controlled manner and then to draw it off into the Danube. A number of variant solutions were considered for that purpose: deep drainage trenches, drainage tunnels and watertight clay membranes implemented in deep trenches. Finally, a solution was implemented using deep wells with drains leading from the wells (Fig. 6).

For the purposes of micro-locating the wells, an additional 12 control boreholes had to be implemented along with six piezometers to determine the depths and thicknesses of the sand layers. The wells were positioned in the stable area of the terrain and had the basic task of draining the water from undisturbed sand; thus, the wells stop the flow of groundwater into the body of the landslide. The two wells are positioned very close to the 
main sliding slopes at $47 \mathrm{~m}$ upstream and $47 \mathrm{~m}$ downstream from the area of the bridge, respectively. Thus, the wells and their drains (up to $45 \mathrm{~m}$ long) provide total terrain drainage in the area of the bridge along a 200 $\mathrm{m}$ stretch.

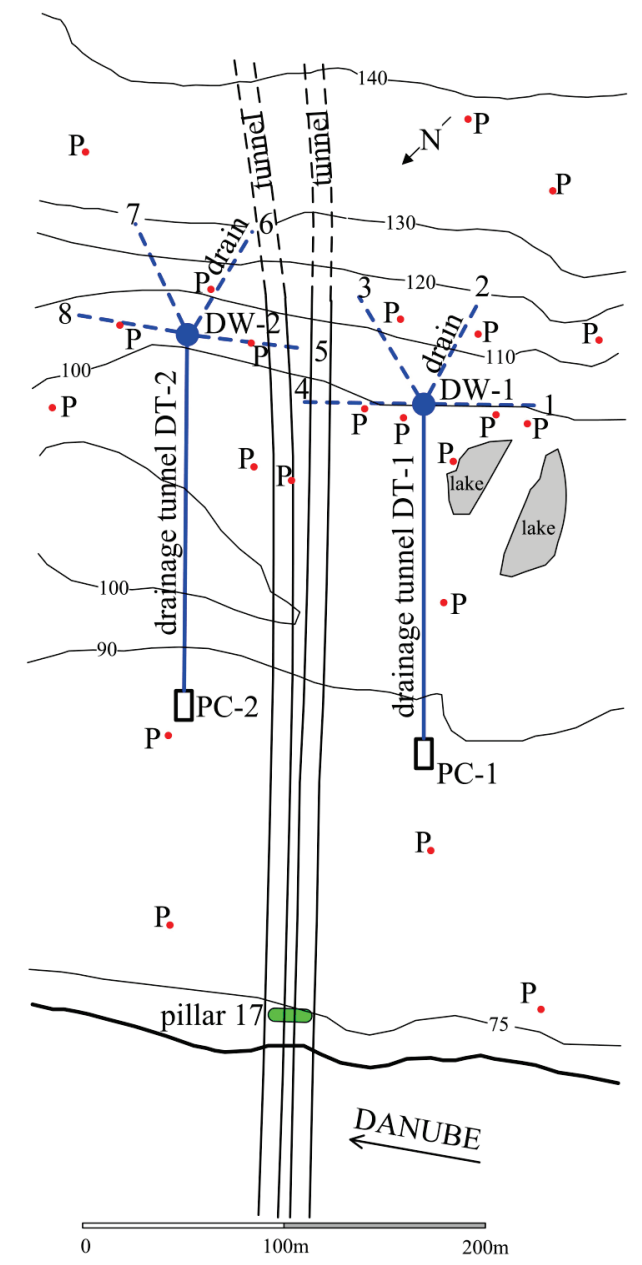

Figure 6 Drainage structures and the distribution of piezometers $\mathrm{P}$

Both drainage wells were $6,5 \mathrm{~m}$ in diameter and $22 \mathrm{~m}$ in depth (Fig. 7). The wells were excavated using heavy machinery while the concrete segments were installed in stages in situ. At the bottom, there was a steel knife of a somewhat larger diameter while the well was being drilled as the excavation process proceeded. The friction of the well casing with the surrounding terrain was reduced by using bentonite. The verticality of the well during construction was controlled geodetically. The wells were pre-fitted with outlet apertures for the horizontal drains in the layer of aquiferous sand. The construction was locally made more difficult by the appearance of lenses and semi-layers of unevenly hardened sandstone and conglomerates. Those sandstones and conglomerates made it exceptionally difficult to insert and form the drains. The positions and lengths of certain drains, especially on well DW-2, were not completed according to design but are substantially shorter. After the well had been drilled to its final depth, a process of underwater lining with concrete was performed and the base of the well was formed.

The construction of the drains stemming from the wells was performed after the wells were completely emptied of water. The drains were constructed in two stages. First, the protective casing was installed whose head contained orifices for the jets used to hydraulically dig and remove the sand. In the loose sand, the installation of the protective casing and removal of the sand was completed without any problems. Problems arose when hardened sand or sandstone was encountered during the installation of the protective casing, and these were impossible to destroy with the jets. The diameter of the protective casing was $500 \mathrm{~mm}$. After the protective casing was installed to the desired length, work began on forming the drains. The drains were made from stainless steel tubes $250 \mathrm{~mm}$ in diameter, and the spaces between the tubes and the protective casings were filled by gravel. In the end, the protective casings were removed and the head with the jets remained at the end of the formed drain. Due to high friction, a large number of stainless steel tubes were crumpled and destroyed as the protective casing was being pulled out. In such cases, the procedure was repeated until the drain was successfully formed.

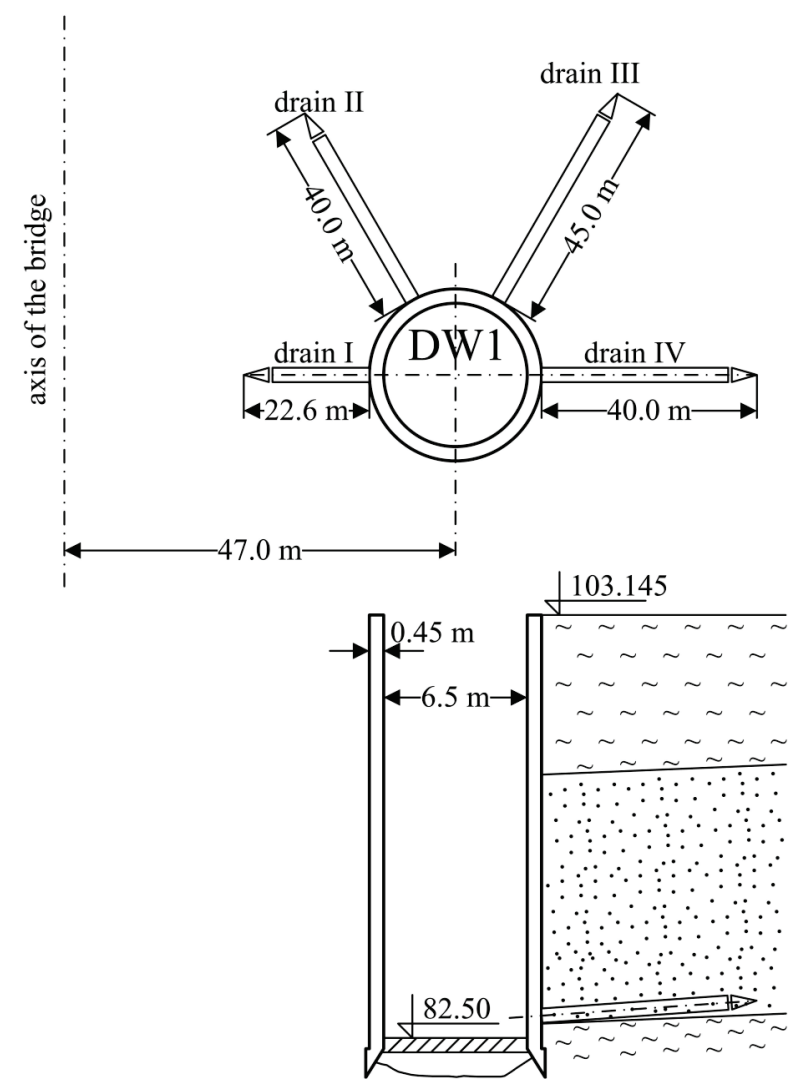

Figure 7 A schematic layout of the DW-1 drainage well and its drains

Of the planned $200 \mathrm{~m}$ of drains leading from DW-1, only $147,6 \mathrm{~m}$ were constructed. In the case of DW-2, only $57,6 \mathrm{~m}$ was constructed out of the planned $200 \mathrm{~m}$. The lengths of the drains on the DW-1 well are satisfactory; this was confirmed in the course of its exploitation. The drains constructed on DW-2 are insufficient, so the installation of new drains is planned.

According to the design, the water from the drainage wells will be channelled into the Danube using gravity. This will mostly be accomplished through two drainage tunnels. A 139-m-long drainage tunnel was constructed leading away from DW-1. Construction was accomplished by pressing prefabricated concrete pipes from the pressure chamber and digging a tunnel using a 
mole encased in a protective steel case. The pipes were installed using laser-guided presses. The work was coordinated in such a way that the mole first penetrated the soil and the material within the steel casings is excavated and brought up to the surface through a tunnel. Successful installation of these concrete tubes was confirmed by the fact that the tunnel was constructed in the designed direction from the pressure chamber to the orifice in well DW-1. The tunnel is currently in operation. During the construction of the tunnel, certain problems were anticipated in the body of the landslide. Surprises occurred at two points when soft muddy sediments were encountered. The technology used for constructing the tunnel did not allow for any deviation from the planned direction. After some delays in the digging of the tunnel, four additional boreholes were drilled and 13 additional cone penetration tests were carried out at a distance of 2,5 $\mathrm{m}$ from each other. The results of the investigation showed that work on digging the tunnel could proceed. The problem of fluid and muddy soil entering the tunnel only confirmed the justifiability of installing the drainage system within the landslide. The two critical points where the fluid and muddy materials appeared coincide completely with the areas of the main sliding planes within the landslide.

Drains are planned to be subsequently constructed from the tunnels. Upon completion, they will be drainage tunnels and not only outlet tunnels, and this will stop the lateral inflow of water into the stabilised area of the landslide.

Plans were also made to press drains from the surface into the sands located between the elevations of $105 \mathrm{~m}$ and $110 \mathrm{~m}$. The water from these drains will also be channelled into the Danube using gravity. These drains will be installed into the drainage area stretching from $100 \mathrm{~m}$ upstream to $100 \mathrm{~m}$ downstream from the bridge.

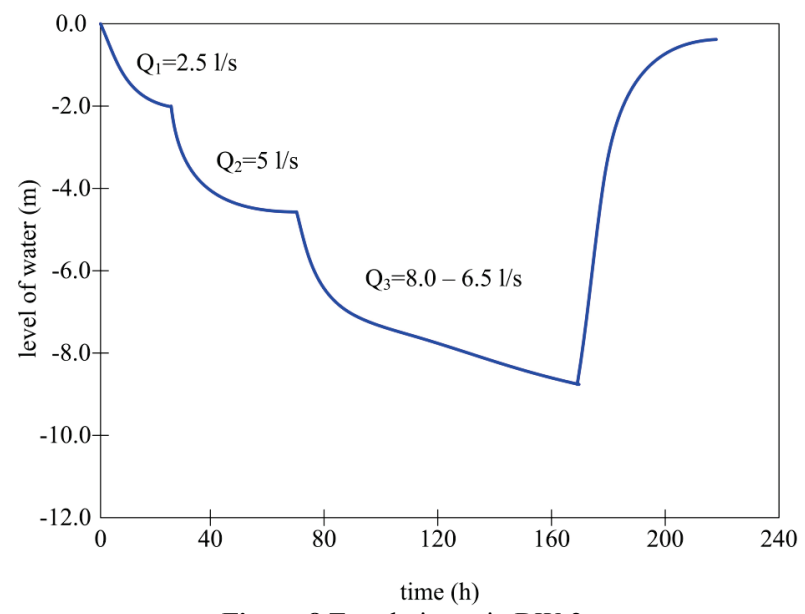

Figure 8 Test drainage in DW-2

After the construction of the wells and all of the drains leading from them, a test drainage was carried out. Tests were performed by measuring the inflow from each of the drains both individually and together. During the test, levels of groundwater were measured using all of the installed piezometers. After the water level within the well stabilised due to the inflow of water from all the drains, test drainage was performed by pumping water from the well. Simultaneously, the levels of groundwater were measured using the piezometers. The testing lasted for approximately a month for each of the wells. Fig. 8 shows the reduction of the water level in drainage well DW-2 in three stages of the test drainage and a restoration of the water level in the well after the drainage ended.

The layer of aquiferous sands in which the drains were installed is approximately $12 \mathrm{~m}$ in thickness. On the Danube slope, these sands are interrupted by landslides. In the stable part of the terrain, the aquiferous sand environment is continual. Measurements from piezometers determined the level of groundwater in the sands containing the drains prior to the test drainage (Fig. 9).

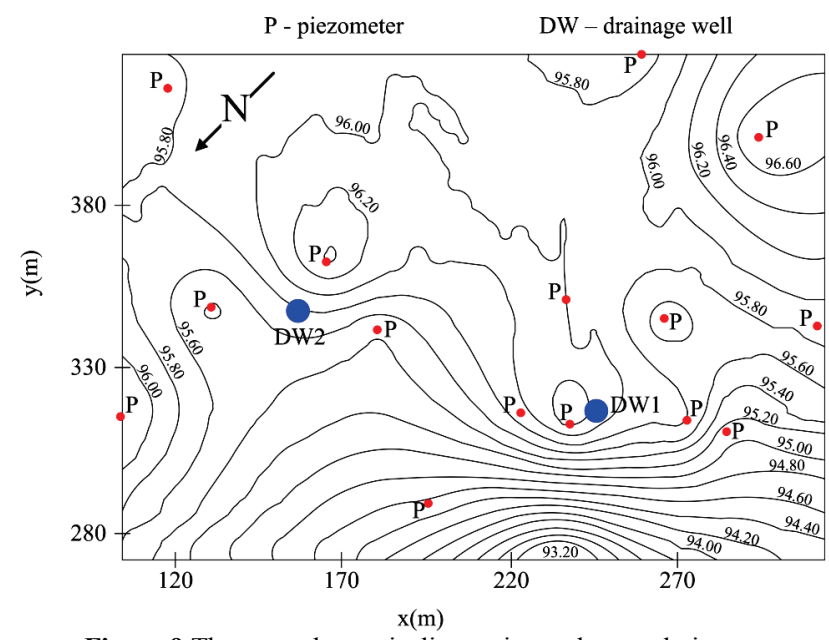

Figure 9 The groundwater isolines prior to the test drainage

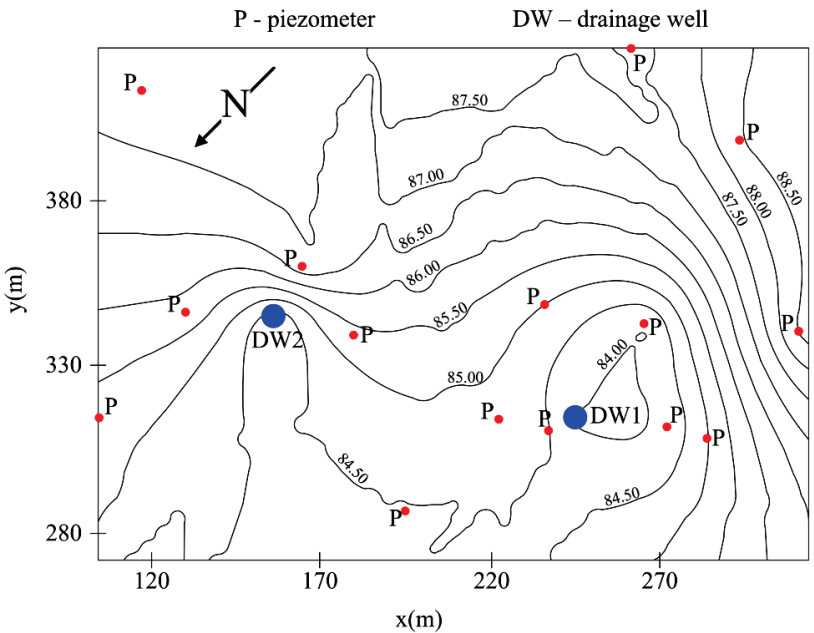

Figure 10 Projected groundwater isolines after pumping for a year

After the test drainage was carried out, the reduction in groundwater levels was measured and the results are shown using isolines in Fig. 10. The isolines refer to the projected decrease in the groundwater levels after a year of drainage. After the test drainages were completed, all the drains in drainage well DW1 were opened to enable the gravitational drainage of water through drainage tunnel DT1 and towards the Danube. The drainage has now proceeded over the course of several years. The landslide is still active as confirmed by measurements using the installed inclinometers and by geodetic measurements. These results indicate the necessity to continue work on the construction of the drainage system in its entirety. 


\section{Conclusion}

The investigation of this landslide has been going on for about 50 years and during that time the degree of investigation of the landslide has constantly been increasing. We would particularly like to point out the investigations that were carried out during the excavation and construction of the two deep drainage wells and the drainage tunnel. That is when the most reliable data was gathered on the groundwater flowing into drainage wells DW-1 and DW-2. The best data on the landslide was gathered by investigations carried out during the excavation of the drainage tunnel through the body of the landslide. Inspection of the drainage tunnel excavation site revealed the main sliding planes. Liquid clay had penetrated the excavated part of the tunnel in the zones of these sliding planes. When that occurred, further excavation was halted and new cone penetration tests (CPTs) were carried out. These CPTs were carried out from the surface of the terrain, along the direction of the drainage tunnel, with penetrations at 2,5-meter intervals. The cone penetration resistances in the soft soil located in the zone of the main sliding plains were less than 0,5 $\mathrm{MPa}$. In the harder zones of the landslide the cone penetration resistances were between 2 and $3 \mathrm{MPa}$.

It has been determined that the cause behind the activation of the landslide was not neotectonic activity along the fault. Namely, exploratory boreholes revealed that the layer of red Pliocene marl was not interrupted by any faults. That layer is located in the zone directly below the landslide. The hypothesis that the main cause of the landslide was groundwater originating from the deeper sand horizons below the landslide was also rejected.

Establishing the monitoring of the landslide has allowed the implementations of partial countermeasures on the landslide. This means that the process of investigating the landslide is not yet complete. New investigations and measurements will be carried out and the project involving the countermeasures will be modified should the need arise. In that respect the terrain investigation for the six concrete box diaphragms which will possibly be carried out in the third stage of implementing the countermeasures for the landslide are particularly insufficient. Further boreholes will be implemented along with the necessary analyses for each concrete box, but only after ascertaining that the drainage system and the Danube bank revetment are not sufficient and that it is necessary to construct the concrete boxes as well.

In Serbia, there are active landslides along 100 kilometers on the right bank of the Danube. The landslides were formed in clayey materials, and the main sliding plains begin at the steep loess horizons. The boreholes that were made through the loess revealed that the sliding process had been active even before the loess was deposited and according to some scientific hypotheses, the loess had a stabilizing influence on those old landslides. Thus, it can be claimed that the expansion of the landslide along the slope can be linked to the degradation of the loess. In addition, it has been determined that the clayey sediments which were altered through influences from the surface were the ones affected by the landslide. Many other landslides in Serbia were also created under such circumstances.

The parameters of the materials within the landslide were determined from a large number of samples in the geomechanics laboratory. The lowest shearing resistance values were obtained from soil samples from the sliding planes. The calculations of the stability of the landslide were carried out with parameters of $c=0, \varphi=8^{\circ}$.

Geodetic measurements of the movements of all the pillars began immediately after the construction of the bridge in 1981. A detailed analysis of the measurement data reliably revealed that the part of the bridge located on the landslide is moving at about $6 \mathrm{~mm}$ per year. Measurements by inclinometers revealed that the landslide is also moving at about $6 \mathrm{~mm}$ per year. It has been confirmed that even foundations on deep piles were not sufficient to prevent the movement of the bridge.

The investigations and stage I countermeasures carried out to date have confirmed the necessity of implementing countermeasures on the landslide. The small amount of movement justifies the approach whereby the monitoring of the bridge and the landslide is compulsory and the partial implementation of the countermeasures by stages is justified.

From a professional aspect, it would be fully justified to implement all the countermeasures simultaneously. That would certainly halt the movement of both the bridge and the landslide. From a scientific aspect, a partial approach of implementing the countermeasures by stages is more acceptable, whereby the effects of each countermeasure can be measured separately.

\section{Acknowledgements}

This work was financially supported by research grants No. TR36043 and TR37017 of the Serbian Ministry of Science and Technological Development.

\section{References}

[1] Gokceoglu, C.; Aksoy, H. Landslide susceptibility mapping of the slopes in the residual soils of the Mengen region (Turkey) by deterministic stability analises and image processing techniques. // Engineering Geology. 44, 1(1996), pp. 147-161. DOI: 10.1016/S0013-7952(97)81260-4

[2] Ercanoglu, M.; Gokceoglu, C. Assessment of landslide susceptibility for a landslide-prone area (north of Yenice, NW Turkey) by fuzzy approach. // Environmental Geology. 41, 6(2002), pp. 720-730. DOI: 10.1007/s00254-001-0454-2

[3] Ercanoglu, M.; Gokceoglu, C. Use of fuzzy relations to produce landslide susceptibility map of a landslide prone area (West Black Sea Region, Turkey). // Engineering Geology. 75, 3(2004), pp. 229-250. DOI: 10.1016/j.enggeo.2004.06.001

[4] Djogo, M.; Vasić, M.; Ćosić, M. Engineering geological evaluation of the conditions for constructing a bridge and a tunnel in the zone of the old Petrovaradin Fortress. // Bull Eng Geol Environ. 70, 1(2011), pp. 139-142. DOl: 10.1007/s10064-010-0292-0

[5] Lokin, P.; Sunarić, D.; Cvetković, T. Landslide in Neogene sediments on the right Danube bank, Yugoslavia. // Fifth international Symposium on Landslide / Lausanne, 1988, pp. 202-208.

[6] Luković, T. Važniji tipovi naših klizišta i mogućnosti njihovog saniranja. // Geološki vesnik. 9, (1951), pp. 50-60. 
[7] Perić, J. Hipoteza o nastanku klizišta u padini duž desne obale Dunava od Vinče do Grocke. // Zbornik radova RGF Beograd, 13, (1970), pp. 35-47.

[8] Marković, M.; Pavlović, R.; Čupković, T. Kabinetska ispitivanja klizišta na desnoj obali Dunava kod Novog Sada. Drugi simpozijum Istraživanje i sanacija klizišta / Donji Milanovac, 1995, pp. 143-150.

[9] Djogo, M.; Vasić, M. Landslide in the area of the bridge on the Danube in Novi Sad. // Proceedings of the ICE Geotechnical Engineering, 164, 1(2011), pp. 3-10. DOI: 10.1680/geng.2011.164.1.3

[10] Lokin, P.; Petričević, M.; Vasić, M.; Janošev, Z. On the Disturbance and Protection of the Geological Medium in Natural Parks with Special Reference to Fruška Gora. // Proceedings on Eighth International Congress, International Association for Engineering Geology and the Environment / Vancouver, 1998, pp. 2659-2666.

[11] Marković, S. et al. Paleoclimate record in the Upper Pleistocene loess-paleosol sequence at Petrovaradin brickyard (Vojvodina, Serbia). // Geologica Carpathica. 56, 6(2005), pp. 545-552.

[12] Marković, S. et al. Late Pleistocene loess-palaeosol sequences in the Vojvodina region, north Serbia. // Journal of Quaternary Science. 23, 1(2008), pp. 73-84. DOI: 10.1002/jqs.1124

[13] Lokin, P.; Vasić, M.; Saković, S.; Petričević, M. Landslide along the Danube Bank at Novi Sad, Yugoslavia. // Proceedings of the $7^{\text {th }}$ International Symposium on Landslide / Trondheim, 1996, pp. 803-808.

\section{Authors' addresses}

Milinko Vasić, PhD, full professor

University of Novi Sad

Faculty of Technical Sciences, Department of Civil Engineering

Trg Dositeja Obradovića 6

21000 Novi Sad, Serbia

\section{Mitar Djogo, PhD, full professor}

University of Novi Sad

Faculty of Technical Sciences, Department of Civil Engineering

Trg Dositeja Obradovića 6

21000 Novi Sad, Serbia

E-mail: mitar@uns.ac.rs

Branko Jelisavac, dipl. ing.

The Highway Institute

Kumodraška 257

11000 Belgrade, Serbia 